\title{
Fos and Jun bind cooperatively to the AP-1 site: reconstitution in vitro
}

\author{
Frank J. Rauscher III, ${ }^{1}$ Pamela J. Voulalas, ${ }^{1}$ B. Robert Franza Jr., ${ }^{2}$ and Tom Curran ${ }^{1}$ \\ ${ }^{1}$ Department of Molecular Oncology, Roche Institute of Molecular Biology, Roche Research Center, Nutley, New Jersey \\ 07110 USA $^{2}$ Cold Spring Harbor Laboratory, Cold Spring Harbor, New York 11724 USA
}

\begin{abstract}
The protein products of the fos (Fos) and iun (Jun) proto-oncogenes have been shown to associate with a DNA element known as the transcription factor activator protein-1 (AP-1) binding site. Jun (previously known as the Fos-binding protein $\mathrm{p} 39$ ) and Fos form a protein complex in the nucleus. To investigate the nature of the association of Fos and Jun with the AP-1 site, and to determine the role of protein complex formation in DNAbinding, we have reconstituted the protein-protein and protein-DNA interactions in vitro using Fos and Jun synthesized in reticulocyte lysates. The Fos-Jun complex formed extremely rapidly in vitro and possessed similar, though not identical, chromatographic and sedimentation properties to the complex isolated from cell extracts. Jun exhibited a low level of AP-1 binding activity; however, this was evident only at high concentrations of DNA. Fos did not bind to the AP-1 site on its own; however, it acted cooperatively with Jun to give enhanced DNA-binding activity. The increased affinity of the Fos-Jun complex for DNA resulted from a stabilization of the protein-DNA complex. These data demonstrate a cooperative interaction between the protein products of two proto-oncogenes with a DNA element involved in transcriptional regulation.
\end{abstract}

[Key Words: Oncogenes; transcription; fos; iun; AP-1; gene regulation]

Received October 21, 1988; revised version accepted November 11, 1988.

Molecular genetic studies have identified several classes of cis-acting nucleotide sequence elements that are responsible for regulating the rate of transcriptional initiation catalyzed by RNA polymerase II-for example, the TATA box (Breathnach and Chambon 1981), the CCAAT box (Myers et al. 1986; Graves et al. 1986), and enhancer elements (Yamamoto 1985; McKnight and Tjian 1986; Maniatis et al. 1987). In combination these sequences contribute to the maintenance of steady-state levels of gene expression and the regulation of tissuespecific gene expression. In addition, enhancers are capable of mediating alterations in transcription rates in response to extracellular stimuli. Insights into the molecular mechanisms responsible for transcriptional regulation are now being made as a result of the identification and characterization of transcription factors.

The transcription factor activator protein-1 (AP-1) was first described as a DNA-binding activity that recognized the enhancer elements of SV40, the human metallothionein $\mathrm{II}_{\mathrm{A}}$ gene, and the control regions of genes whose expression is stimulated by treatment of cells with the phorbol ester (12-O-tetradecanoyl phorbol-13acetate) (Angel et al. 1987; Lee et al. 1987a,b). Many cell types have been found to contain AP-1 binding activity and binding sites have been located within several negative and positive regulatory elements (Piette and Yaniv 1987; Franza et al. 1988; Rauscher et al. 1988a). The levels of AP-1 binding activity increase after cells are treated with a variety of stimulatory agents including serum, nerve growth factor, and the calcium ionophore
A23187 (Franza et al. 1988; Rauscher et al. 1988a). These observations suggested that AP-1 may be involved in many aspects of gene regulation. Indeed, affinity-purified preparations of AP-1 contain several polypeptides in the 35- to $50-\mathrm{kD}$ range (Lee et al. $1987 \mathrm{~b}$; Rauscher et al. $1988 \mathrm{~b})$. The first of these proteins to be identified was the product of the jun proto-oncogene (Jun) (Bohmann et al. 1987). The jun oncogene is carried by avian sarcoma virus 17 (Maki et al. 1987). The possibility that it might encode a transcription factor was raised by the observation of a protein sequence similarity with the yeast transcription factor GCN4 (Vogt et al. 1987). GCN4 is responsible for inducing expression of several genes involved in amino acid biosynthesis in yeast (Hope and Struhl 1986). It binds as a dimer to a target sequence that is related closely to the AP-1 binding site (Hill et al. 1986; Hope and Struhl 1987). Using anti-Jun antibodies, the c-jun product was identified among the collection of AP-1 polypeptides (Bohmann et al. 1987; Bos et al. 1988). A completely different line of research identified another oncogene product (Fos) as an AP-1 protein (Distel et al. 1987; Franza et al. 1988; Rauscher et al. 1988a). The fos oncogene is responsible for the induction of osteogenic sarcomas by the FBJ and FBR murine sarcoma viruses (Curran and Teich 1982a; Curran and Verma 1984). It encodes a $62-\mathrm{kD}$ phosphoprotein (Fos) that forms a protein complex with a $39-\mathrm{kD}$ protein $(\mathrm{p} 39)$ in the nucleus (Curran et al. 1984, 1985). This protein complex is associated with chromatin and binds to DNA cellulose in vitro (Sambucetti and Curran 1986). A se- 
quence-specific DNA-binding activity involving Fos was first indicated by experiments that showed inhibition of a gel-shift complex, involving a regulatory element from a gene expressed in adipocytes, by anti-Fos antibodies (Distel et al. 1987). The exact binding site was identified as the AP-1 target sequence by mutagenesis, competition, and affinity-purification studies (Franza et al. 1988; R'auscher et al. 1988a). Using anti-Fos antibodies, Fos and several Fos-related antigens (Fra) were identified among AP-1 polypeptides purified using oligonucleotide affinity columns (Rauscher et al. 1988b). Fra represent a set of proteins that are induced in many of the same circumstances as Fos (Franza et al. 1987b). At least one of these, Fra-1, contains several regions of homology with Fos (Cohen and Curran 1988). These studies demonstrated that several proteins can bind to AP-1 sites directly or indirectly via protein-protein interactions. Therefore, the term AP-1 should be used to refer to a DNA-binding activity and not to a specific gene or gene product.

The connection between Fos and Jun was established by the discovery that the Fos-associated protein p39 is the product of c-jun (Rauscher et al. 1988b). This suggested that transcription factor AP-1 is comprised, at least in part, of a protein complex containing Fos and Jun. To assess the respective roles of Fos and Jun in DNA binding, we have attempted to reconstitute the Fos-Jun-AP-1 site complex in vitro using full-length proteins synthesized in reticulocyte lysates. Here we show that Fos and Jun bind to DNA cooperatively. Although Jun does bind to the AP-1 site in the absence of Fos, the Fos-Jun complex binds with a much higher affinity, primarily because of increased stability.

\section{Results}

Fos and Jun associate in vitro

Rat cDNA clones containing the complete c-fos and c-jun open reading frames were used to generate synthetic RNAs as described in Materials and methods. The structure of these clones is illustrated in Figure 1. Translation of c-fos RNA in a rabbit reticulocyte lysate yielded a series of polypeptides in the $55-$ to $68-\mathrm{kD}$ range that could be immunoprecipitated with anti-Fos antibodies (F) but not with anti-Jun antibodies (J) (Fig. 2). The heterogeneity in apparent molecular weight of Fos is a consequence of varying degrees of post-translational modification. Previous studies demonstrated that part of the modification process is regulated by the cAMP-dependent protein kinase in reticulocyte lysates (Curran et al. 1987).

The major translation products of c-jun RNA appeared as three polypeptides in the 40 - to $50-\mathrm{kD}$ range that were precipitated by anti-Jun (J) but not by anti-Fos $(F)$ antibodies (Fig. 2). Thus, although Fos and Jun exhibit sequence similarities in the antibody-binding domains, they are not immunologically cross-reactive. The Pep-1 and Pep- 2 anti-Jun antibodies described by Bos et al. (1988) also did not recognize Fos synthesized in vitro (data not shown).
As little as 2-5 min after mixing reticulocyte lysates containing Fos and Jun, anti-Fos antibodies precipitated a small amount of Jun, and anti-Jun antibodies precipitated a small amount of Fos (Fig. 2), indicating that FosJun complexes formed extremely rapidly in vitro. The association continued, and increasing amounts of FosJun complexes were detected by co-precipitation, for up to $30 \mathrm{~min}$ of incubation at $37^{\circ} \mathrm{C}$. Similar results were obtained by co-translating c-fos and c-jun RNAs in the same reticulocyte lysate (data not shown). The efficiency of complex formation was not improved by cotranslation; rather it appeared to be related only to the time of incubation.

Interestingly, a larger-molecular-weight protein species $(100-120 \mathrm{kD})$ was precipitated by both anti-Fos and anti-Jun antibodies at later time points (indicated by an arrowhead in Fig. 2). This band may represent FosJun heterodimers that were not dissociated by boiling in gel loading buffer. A $30-\mathrm{kD}$ Jun polypeptide is also pointed out by an arrowhead in Figure 2. This protein is most likely an internal initiation product of the c-jun RNA. It is immunoprecipitated by Pep-1 but not by Pep- 2 anti-Jun antibodies, suggesting that it represents a carboxy-terminal fragment of Jun (data not shown). This smaller protein also participated in complex formation with Fos, suggesting that the protein-binding domain of Jun, like the DNA-binding domain (Bos et al. 1988), is located in the carboxy-terminal portion of the protein.

The Fos-Jun complex formed in vitro seemed to be as stable as that isolated from cell nuclei. It was not dissociated by the presence of $0.1 \%$ SDS, $1 \%$ NP- 40 , and $1 \%$ sodium deoxycholate in the immunoprecipitation (RIPA) buffer. Furthermore, the Fos-Jun complex was not disrupted by treatment with $2 \mathrm{M} \mathrm{KCl}$ (data not shown).

\section{Jun undergoes RNase A-sensitive modification in vitro}

Although the major Jun polypeptide synthesized in vitro had the same mobility on SDS-polyacrylamide gels and the same tryptic peptide map as Jun isolated from cell extracts (Rauscher et al. 1988b; data not shown), several larger-molecular-weight species were also detected (Fig. 2). To determine whether these other polypeptides represented post-translationally modified forms of Jun, we investigated the time course of Jun synthesis in vitro. As shown in Figure 3A, the higher-molecular-weight forms of Jun accumulated at later time points, and at $60 \mathrm{~min}$ (lane 5) there was a diminution in the amount of the primary translation product. This suggested that the larger Jun polypeptides were generated by post-translational modification; however, it is possible that some arose by co-translational modification. In the case of Fos, some of the modifications were shown to be catalyzed by cAMP-dependent kinase, as modification was stimulated by addition of cAMP to the lysate and several forms were lost following phosphatase treatment (Curran et al. 1987). Although p39 ${ }^{\mathrm{c}-\text { iun }}$ is phosphorylated in vivo (Curran et al. 1984), neither of these treatments affected the post-translational modification detected in vitro (data not shown). An observation of the effects of 
CDNA CLONES USED FOR in vitro EXPRESSION

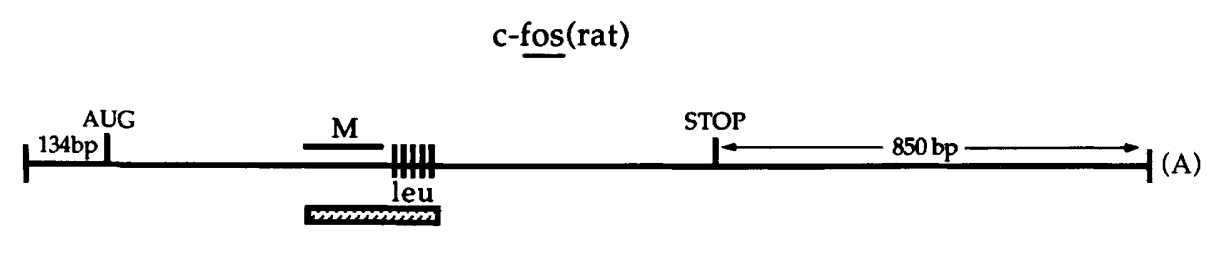

$2.1 \mathrm{kbp}$

c-jun(rat)

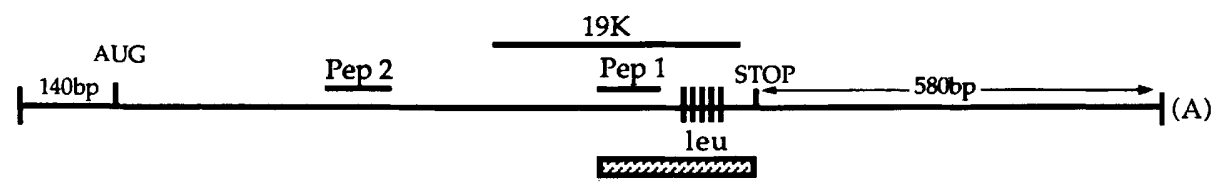

$1.8 \mathrm{kbp}$

Fos, Fra, Jun, GCN4-related region

Figure 1. Structure of cDNA clones used for in vitro expression. The 2.1-kbp c-fos(rat) and 1.8-kbp c-jun(rat) cDNAs are illustrated diagramatically. The c-fos structure is from Curran et al. (1987). The positions of the c-jun initiator AUG and stop codons are based on comparisons with the c-jun(human) (Bohmann et al. 1987) and c-jun(mouse) (Ryseck et al. 1988) sequences. M indicates the position of the 127-152 amino acid region used to generate anti-Fos antibodies (Curran et al. 1985). Similarly, the Pep 1 (amino acids 209-225), Pep 2 (amino acids 73-87), and carboxy-terminal 19-kD regions used to make anti-Jun antibodies are indicated (Bos et al. 1988; Bohmann and Tjian, pers. comm.). The position of the proposed leucine zipper (leu) (Landschulz et al. 1988a) and the region of sequence similarity between Fos, Fra-1, Jun, and GCN4 (Vogt et al. 1987; Cohen and Curran 1988) are shown.

ribonuclease (RNase), first made by T. Bos and P.K. Vogt (University of Southern California, pers. comm.), suggested that the in vitro Jun modifications occurred by a totally independent mechanism. As shown in Figure 3B, the majority of the larger forms of Jun (lane 4) were converted to a single species that comigrated with the primary translation product after $30 \mathrm{~min}$ of treatment with RNase A (lane 8). In contrast, the several forms of Fos (lane 1) were unaffected by RNase treatment (lane 5). Since sample preparation for gel electrophoresis requires boiling in $2 \%$ SDS under reducing conditions, these data suggest that the altered mobility of Jun is a result of the covalent attachment of polyribonucleotides. However, it is also possible that Jun binds tightly but noncovalently to RNA present in the reticulocyte lysate. Two oncogene products, p53 (Samad et al. 1986) and SV40 large T antigen (Carroll et al. 1988), have been shown to be modified by addition of ribonucleotides; however, the efficiency and extent of the Jun alterations are unparalleled in reticulocyte lysates. Some modified forms of Jun are detected in vivo (Curran et al. 1984; Franza et al. 1987b), but it is not clear if they contain the same modifications as Jun synthesized in vitro. The precise nature and site of modifications on Jun are not yet known. However, modification does not appear to affect the rate or extent of Fos-Jun complex formation in vitro (data not shown).

Comparison of Fos-Jun complex formed in vitro and in vivo

The precipitation of the in vitro-formed Fos-Jun complex with anti-Jun antibodies was somewhat surprising because previously we were unable to immunoprecipitate the complex from cell extracts with anti-Jun antibodies (Rauscher et al. 1988b; data not shown). In fact, it appeared that anti-Jun antibodies disrupted the Fos-Jun complex. This suggested that there were differences between the complexes formed in vitro and in vivo. To compare the properties of the complexes directly, we analyzed their migration properties on sucrose gradients and gel filtration columns. $\left.{ }^{35} \mathrm{~S}\right]$ Methionine-labeled extracts of serum-stimulated rat fibroblasts (Fig. 4A) and reticulocyte lysates containing Fos-Jun complexes (Fig. 4B) were analyzed by sedimentation through a sucrose gradient, and fractions were treated with anti-Fos antibodies. As anti-Fos antibodies were used for detection, and these do not recognize Jun, the position of Jun gave 
Figure 2. Association of Fos and Jun in vitro. c-fos and c-jun RNAs were translated in vitro and the products were immunoprecipitated with anti-Fos $(F)$ or anti-Jun $(J)$ antibodies. Immunoprecipitation was carried out prior to mixing the Fos- and Juncontaining reticulocyte lysates (c-fos, c-jun) and at the indicated times after mixing and incubation at $37^{\circ} \mathrm{C}$ (c-fos + c-jun). (Lane $M$ ) Molecular weight markers. The positions of the Fos and Jun polypeptides are indicated.

an indication of the complex size. The antibody used for detection in this particular experiment /a kind gift of D. Slamon, UCLA Medical School) does not recognize Fosrelated antigens; therefore, only Fos and Jun were precipitated from these cell extracts. Both the in vitro- and the in vivo-formed complexes migrated with an apparent molecular mass of $45 \mathrm{kD}$. This was rather smaller than expected even if the complex were only a dimer, as Fos has a predicted molecular mass of $42 \mathrm{kD}$ and Jun of 37 $\mathrm{kD}$. In contrast, gel filtration chromatography on a 300 SW FPLC column gave apparent sizes of $210 \mathrm{kD}$ for the in vivo complexes (Fig. $4 \mathrm{C}$ ) and $400 \mathrm{kD}$ for the in vitro complex (Fig. 4D). The in vitro complex had a pronounced shoulder that extended into the $300-\mathrm{kD}$ range. Thus, Jun-Fos complexes exhibit a much larger apparent molecular mass by size-exclusion chromatography than by sucrose gradient sedimentation. This behavior suggests that the complex has an elongated shape that could cause drag on sucrose gradients and give a

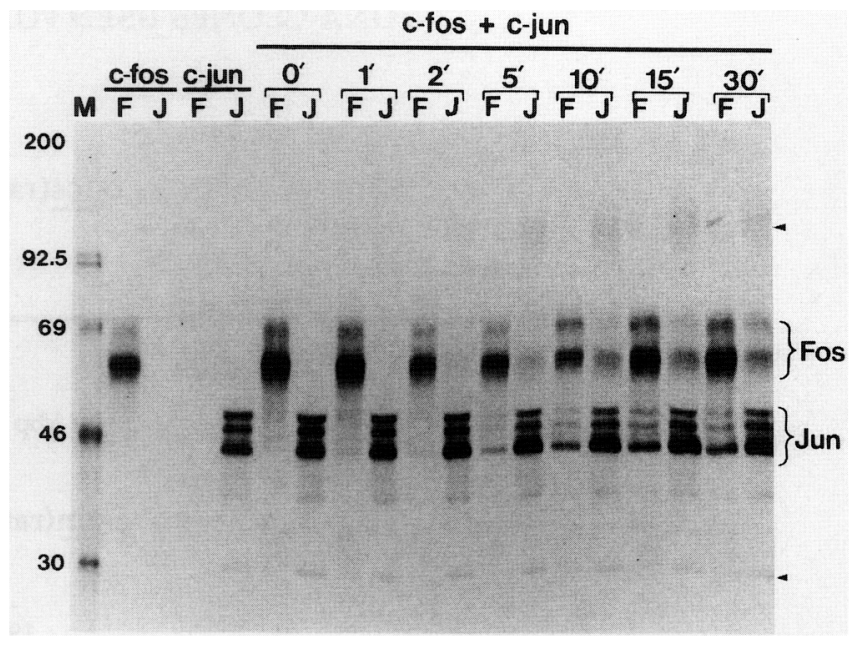

Stokes radius on size-exclusion columns that is larger than expected. Interestingly, transcription factor IIIB has similar migration properties (Klekamp and Weil 1987). It is possible that the in vitro-formed Fos-Jun complex is less tightly packed than the in vivo complex, causing a larger apparent molecular mass on size-exclusion columns and allowing access of the anti-Jun antibodies for immunoprecipitation.

\section{Fos-Jun complex formed in vitro binds to AP-1 sites}

Several proteins, including Fos, Fos-related antigens, and Jun, have been identified by affinity chromatography using oligonucleotides containing AP-1 sites (Bohmann et al. 1987; Franza et al. 1988; Rauscher et al.1988b). The finding that anti-Fos antibodies inhibit the AP-1 binding activity present in cell extracts suggests that Fos and/or Fra contribute to AP-1 activity (Rauscher et al. 1988a). However, a purified carboxy-terminal fragment of Jun,
Figure 3. Jun undergoes RNase-sensitive modification in vitro. $(A)$ Time-course of Jun synthesis. c-jun RNA was translated in a messenger-dependent reticulocyte lysate in the presence of $\left[{ }^{35} \mathrm{~S}\right]$ methionine. Samples were removed after $0 \mathrm{~min}$ (lane 1), $5 \mathrm{~min}$ (lane 2), $15 \mathrm{~min}$ (lane 3), $30 \mathrm{~min}$ (lane 4), and 60 min (lane 5) and placed on ice before being analyzed by electrophoresis on an SDS-polyacrylamide gel. The positions of the Jun polypeptides are indicated by arrowheads. (Lane M) ${ }^{14} \mathrm{C}$-Methylated marker proteins (Amersham). (B) RNase A treatment of Jun synthesized in vitro. c-fos (lanes 1,2, 5, and 6) and c-jun (lanes 3, 4, 7, and 8) RNAs were translated in reticulocyte lysates and the products were immunoprecipitated with anti-Fos $(F)$ or anti-Jun $(I)$ antibodies before (lanes $1-4)$ and after (lanes 5-8) a 30-min treatment with RNase A. The immunoprecipitation products were analyzed on a 9\% SDS-polyacrylamide gel. Arrowheads indicate the positions of Fos and Jun.

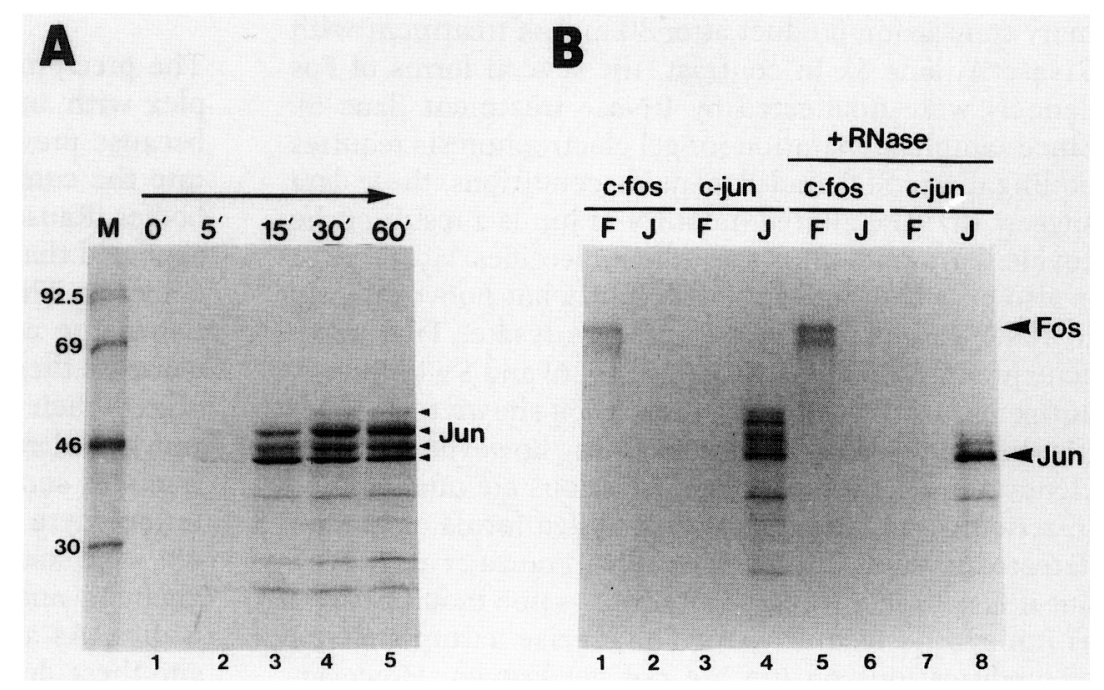




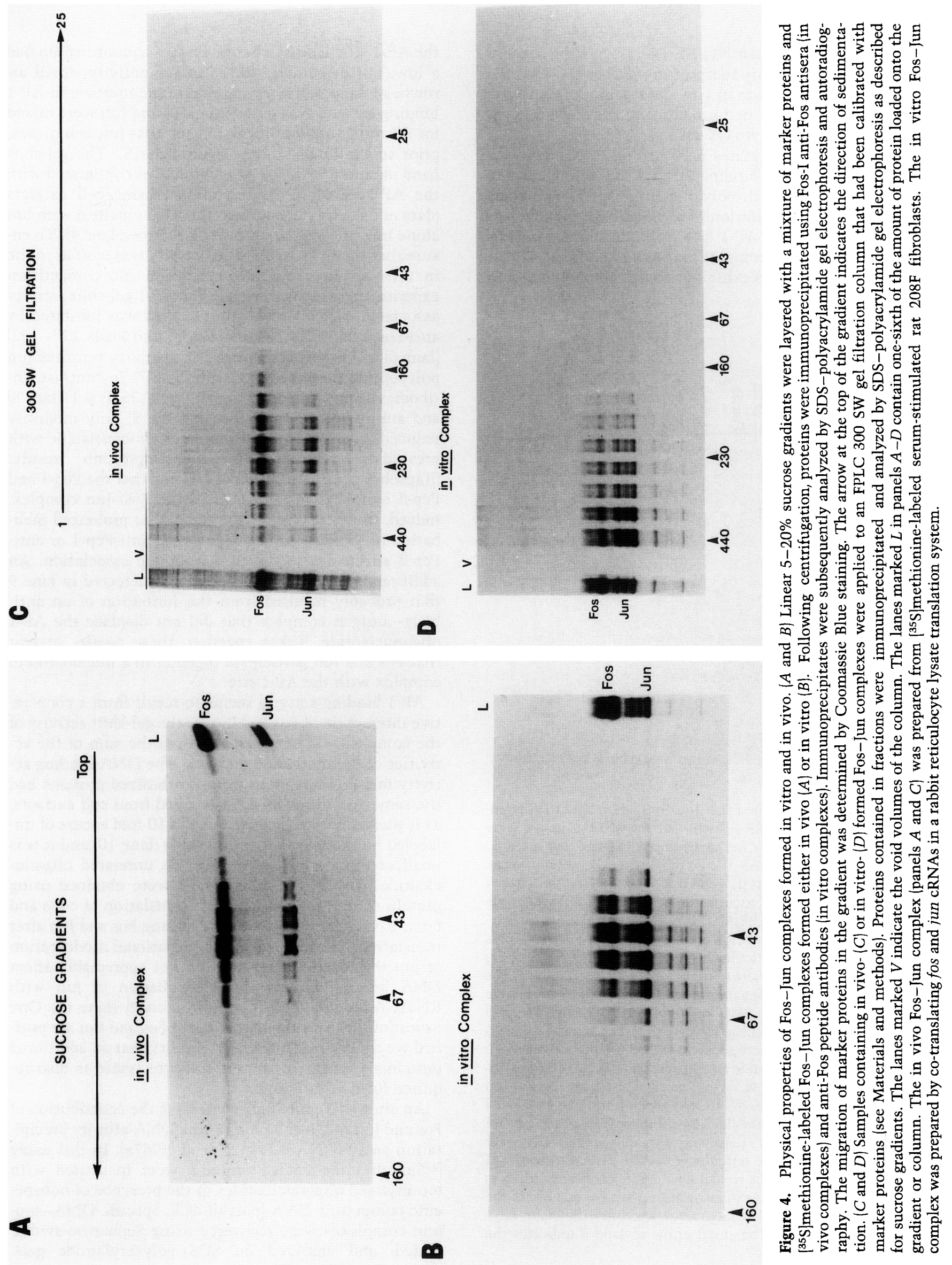


produced in E. coli, exhibits AP-1 DNA-binding activity as measured by DNase footprinting (Bos et al. 1988). To assess the contribution of Fos to AP-1 binding activity, gel-shift assays were performed using Fos and Jun, synthesized in reticulocyte lysates.

The reticulocyte lysates used had a high background of nonspecific DNA-binding activity that was abolished by preincubation with poly $(\mathrm{dI}-\mathrm{dC})$ nonspecific competitor DNA prior to addition of a ${ }^{32} \mathrm{P}$-labeled oligonucleotide containing the AP-1 site from the human metallothionein $\mathrm{II}_{\mathrm{A}}$ gene (compare lanes 1 and 2, Fig. 5). The in vitro-synthesized Fos exhibited no detectable binding to

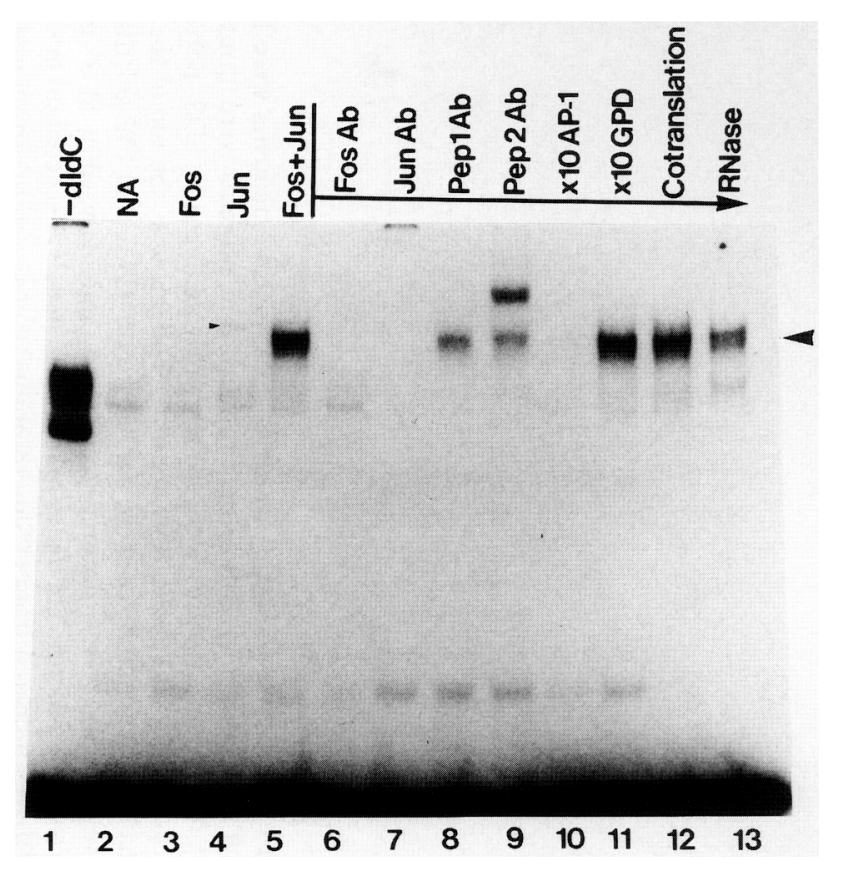

Figure 5. In vitro-formed Fos-Jun complexes bind to oligonucleotides containing AP-1 sites. Gel retardation assays were performed using Fos or Jun synthesized in vitro and a ${ }^{32} \mathrm{P}-\mathrm{la}$ beled oligonucleotide (AP-1) containing the AP-1 site from the human metallothionein $\mathrm{II}_{\mathrm{A}}$ gene (Lee et al. 1987a ; Rauscher et al. 1988a). (Lane 1) Reticulocyte lysates without exogenous RNA incubated with [32P]AP-1 minus poly $(\mathrm{dI}-\mathrm{dC}$ ); (lane 2) lysates without exogenous RNA incubated with [32P|AP-1 plus poly(dI-dC); (lane 3) reticulocyte lysate containing Fos protein; (lane 4) reticulocyte lysate containing Jun protein; (lane 5) Fos and Jun synthesized separately in reticulocyte lysates were mixed and incubated at $37^{\circ} \mathrm{C}$ for $30 \mathrm{~min}$ prior to assay. Samples in lanes 6-11 were incubated exactly as that shown in lane 5 except the following were added to the gel retardation reaction: (lane 6) anti-Fos $M$ peptide antibodies; (lane 7) anti-p19-Jun antibodies; (lane 8 ) anti-Jun Pep-1 antibodies; (lane 9) anti-Jun Pep-2 antibodies; (lane 10) 10-fold molar excess of unlabeled AP-1 oligonucleotide; and (lane 11) 10-fold excess of the control (GPD) oligonucleotide. (Lane 12) fos and jun cRNAs were translated in the same reticulocyte lysate prior to use in gel retardation; (lane 13) the reticulocyte lysate containing Jun was treated with RNase prior to association with Fos and use in the gel retardation assay. The large arrow indicates the major FosJun-DNA complex. The small arrow in lane 4 indicates the Jun-DNA complex. the AP-1 site (lane 3) whereas lysates containing Jun had a low, but detectable, AP-1 binding activity (small arrowhead, lane 4). However, a dramatic increase in AP-1 binding activity was observed if Fos and Jun were mixed for $30 \mathrm{~min}$, to allow formation of Fos-Jun complexes, prior to the DNA-binding assay (lane 5). The gel-shift band obtained with Fos-Jun complexes comigrated with the AP-1 gel-shift band generated using cell extracts (data not shown). In contrast, the band obtained with Jun alone migrated slightly slower (see arrow, lane 4). To ensure that the in vitro gel-shift activity was similar to the in vivo activity, antibody inhibition and competition experiments were performed. The AP-1 gel-shift activity associated with the Fos-Jun complex was inhibited by anti-Fos antibodies (against Fos amino acids 127-152) (lane 6) and by antibodies against a carboxy-terminal Jun polypeptide expressed in $E$. coli (lane 7). In contrast, antibodies against Jun amino acids 209-225 (Pep-1) (lane 8) and amino acids $73-87$ (Pep-2) (lane 9) only modestly reduced AP-1 binding activity. This is consistent with previously reported immunoprecipitation results (Rauscher et al. 1988b) demonstrating that the Pep-1 and Pep-2 epitopes were masked in the Fos-Jun complex. Indeed, these experiments revealed that prolonged incubation of the Fos-Jun complex with anti-Pep-1 or antiPep-2 antibodies served to disrupt the association. An additional, 'super-retarded' band was detected in lane 9 that probably resulted from the formation of an antibody-antigen complex that did not displace the AP-1 oligonucleotide. Taken together, these results suggest that Fos and Jun participate together in a nucleoprotein complex with the AP-1 site.

AP-1 binding activity seems to result from a cooperative interaction of Fos and Jun, as the gel-shift activity of the complex was much greater than the sum of the activities of the individual proteins. The DNA-binding activity measured using in vitro-synthesized proteins had the same specificity as AP-1 purified from cell extracts, as it was competed by addition of a 10-fold excess of unlabeled homologous oligonucleotide (lane 10) and it was unaffected by competition with an unrelated oligonucleotide (lane 11). Similar results were obtained using protein complexes formed by co-translation of $\mathrm{c}-f \circ s$ and c-jun RNAs (lane 12) instead of mixing Fos and Jun after translation. The unusual post-translational modification of Jun that occurred in vitro did not appreciably affect DNA binding because prior incubation of Jun with RNase A did not abolish gel-shift activity (lane 13). One caveat of these results is that, until Fos and Jun are purified we cannot rule out the possibility that an additional protein/s) present in the reticulocyte lysate is also required for AP-1 binding.

An alternative method of assessing the contribution of Fos and Jun to DNA binding is the DNA-affinity precipitation assay (DNAP, Franza et al. 1987a). In this assay ${ }^{35}$ S]methionine-labeled proteins were incubated with biotinylated oligonucleotides in the presence of nonspecific competitor DNA [poly(dI-dC)]. Specific DNA-protein complexes were recovered using Sepharose-avidin, eluted, and analyzed on SDS-polyacrylamide gels. 
Figure 6 shows that while Jun was recovered using an AP-1 site from the gibbon ape leukemia virus (GALV) (lane 3) Fos was not (lane 4). Mixing of Fos and Jun prior to the assay resulted in the recovery of Fos and an increase in the recovery of Jun (lanes 5 and 6). Similar results were obtained with other AP-1 sites, such as the $\mathrm{HMTII}_{\mathrm{A}} \mathrm{AP}-1$ site (lane 7) and the closely related cAMPresponsive element (CRE) from the somatostatin gene (lane 8). However, only a small amount of Jun was recovered using an unrelated oligonucleotide containing a NFкB binding site (lane 9).

\section{Effect of DNA concentration on AP-1 binding}

Gel-shift assays (Fig. 5) indicated that there was a much greater difference in the AP-1 binding activity of the Fos-Jun complex compared to Jun alone than that observed in DNAP assays (Fig. 6). One major difference between these two assays is that a much higher concentra-

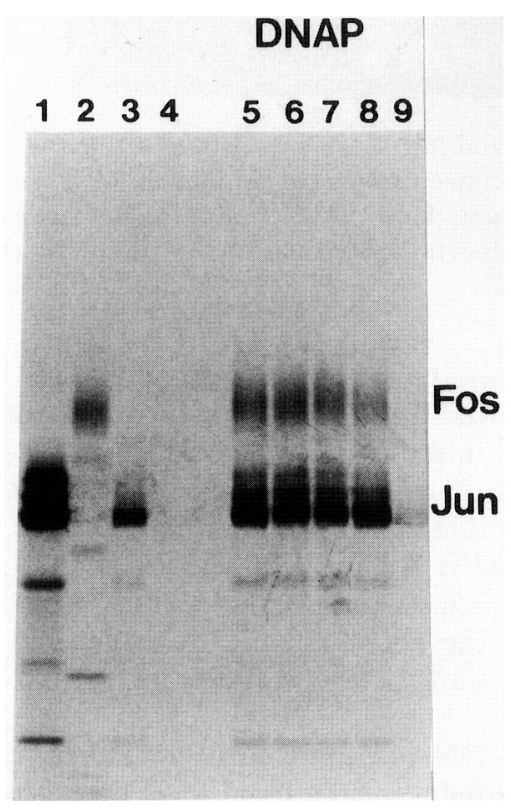

Figure 6. Detection of Fos-Jun complex binding to DNA using the DNA affinity precipitation assay. The biotinylated oligonucleotides that were used in DNAP assays (Franza et al. 1987a) are described in Materials and methods. The binding reaction contained $\left.{ }^{35} \mathrm{~S}\right]$ methionine-labeled, Fos, Jun, or Fos + Jun in a total volume of $60 \mu$ containing 20 pmoles of biotinylated oligonucleotide, $50 \mathrm{mM} \mathrm{KCl}$, and either a 40 -fold (lane 5) or a 100-fold excess by weight (lanes 3, 4, 6-9) of poly(dI-dC) nonspecific competitor DNA. Proteins that bound to the oligonucleotide were recovered on streptavidin-agarose and analyzed by SDS-PAGE. (Lanes 1 and 2) Jun and Fos proteins present in the reticulocyte lysates prior to use in the DNAP assay. The proteins and oligonucleotide probes used in each lane are as follows: (lane 3) Jun alone, DGALV (the AP-1 site from the gibbon-ape leukemia virus LTR) probe; (lane 4) Fos alone, DGALV probe; (lane 5) Fos + Jun, DGALV probe; (lane 6) Fos + Jun, DGALV probe; (lane 7) Fos + Jun, DAP-1 (the $\mathrm{HMTII}_{\mathrm{A}}$ AP-1 site) probe; (lane 8) Fos + Jun, STAT (the somatostatin cAMP-responsive element, CRE) probe; (lane 9) Fos + Jun, Kappa B Probe. tion of AP-1 sites was used in the DNAP assay. To investigate the role of DNA concentration in DNA-protein complex formation, we examined the effect of increasing the oligonucleotide concentration on gel-shift activity. Preliminary experiments demonstrated that binding of Jun, or Fos + Jun, to the AP-1 site reached equilibrium within 15 min (data not shown). Even at the highest concentration of oligonucleotide used, Fos alone exhibited no obvious specific DNAbinding activity above background compared to a reticulocyte lysate without added RNA (NA, Fig. 7). Jun did not bind to low concentrations of the AP-1 site, indeed an increase in the nonspecific background bands with increasing DNA concentration was evident before Jun binding was detected. Thereafter, the level of Jun binding increased in proportion to the amount of input DNA. These results were very surprising because, even at the lowest concentration of input DNA, the AP-1 site was in excess, as illustrated by the unbound oligonucleotide migrating at the bottom of the gel. In contrast, Fos-Jun complexes exhibited AP-1 binding activity at the lowest concentration $(0.66 \mathrm{nM})$ of oligonucleotide tested. These results confirmed the suggestion of a strong cooperative effect of Fos and Jun on DNA-binding activity. However, the difference between Jun and Fos plus Jun depended on the concentration of AP-1 sites used in the assay. The binding activity of the Fos-Jun complex reached a plateau at an oligonucleotide concentration of $0.052 \mu \mathrm{M}$; whereas the Jun DNA-binding activity continued to increase with rising DNA concentrations. Thus, formation of the protein-DNA complex was stimulated by raising the DNA concentration.

A heterogeneous smear of oligonucleotide migration was detected at high concentrations of the AP-1 site using reticulocyte lysates containing Fos or Jun, that was not present in control lysates (NA, Fig. 7). One possible explanation for this smear was that it represented oligonucleotides that dissociated from Fos or Jun during the running of the gel. Although oligonucleotides may be trapped by a caging effect in the gel-shift band, they will be lost more readily from the band if the DNA-protein association is of low-affinity. Fos does exhibit nonspecific DNA-binding activity (Sambucetti and Curran 1986) and it is possible that it has a low affinity for AP-1 sites that cannot be readily measured by the assays used here.

Analysis of the migration of $\left[{ }^{35} S\right]$ methionine-labeled protein complexes on low-ionic-strength gels indicated that the AP-1 oligonucleotide can affect complex formation. Figure 8 (lane 1 ) shows the $\left[{ }^{35} \mathrm{~S}\right]$ methionine-labeled background bands that appeared in lysates incubated without exogenous RNA. Fos did not resolve well in this gel system and appeared as a smear near the top of the gel (lane 2). Jun migrated as a set of bands near the top of the gel (lane 3). The smear of $\left[{ }^{35} \mathrm{~S}\right]$ methionine-labeled Fos (lane 1) was converted into a tighter band that comigrated with [ $\left.{ }^{35} \mathrm{~S}\right] \mathrm{methionine-labeled} \mathrm{Jun,} \mathrm{by} \mathrm{prior} \mathrm{incuba-}$ tion with unlabeled Jun (lane 3). Similarly, a mixture of $\left[{ }^{35} \mathrm{~S}\right]$ methionine-labeled Jun and unlabeled Fos (lane 5), migrated in the same region of the gel. However, when 

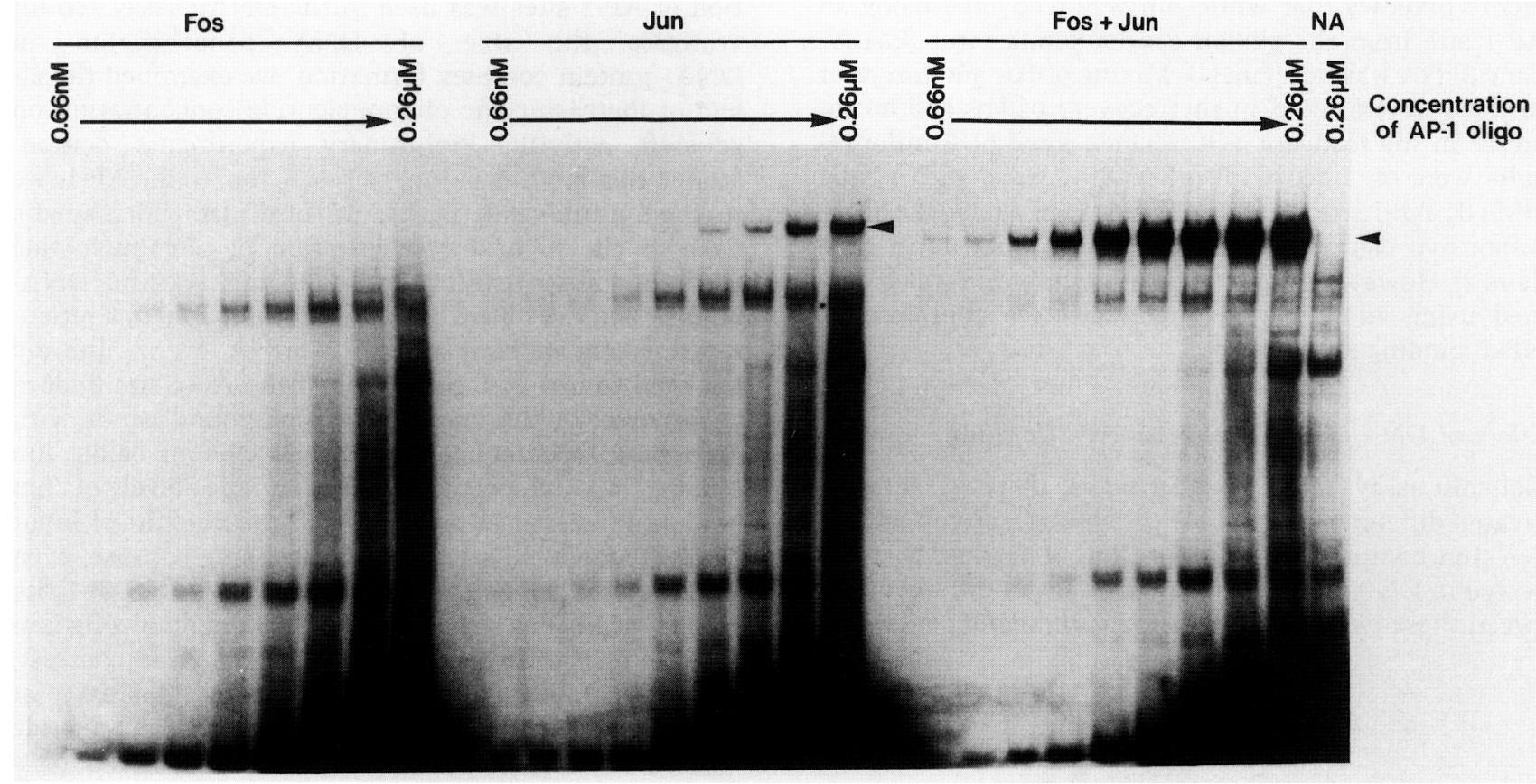

Figure 7. The effect of DNA concentration on the AP-1 binding activity of Fos and Jun. Gel retardation reactions were assembled with reticulocyte lysates containing Fos, Jun, or Fos + Jun and the following final concentrations of ${ }^{32}$ P-labeled AP-1 oligonucleotide: $0.66 \mathrm{nM}, 1.32 \mathrm{nM}, 2.64 \mathrm{nM}, 5.20 \mathrm{nM}, 0.013 \mu \mathrm{M}, 0.026 \mu \mathrm{M}, 0.052 \mu \mathrm{M}, 0.13 \mu \mathrm{M}, 0.26 \mu \mathrm{M}$. (Lane $N A$ ) Gel retardation reaction carried out using a concentration of $0.26 \mu \mathrm{M}$ of ${ }^{32} \mathrm{P}$-labeled AP-1 oligonucleotide and reticulocyte lysate incubated without added RNA. The arrows indicate the positions of the Jun-DNA and the Fos-Jun DNA complexes.

the Fos-Jun complexes were incubated with an excess of unlabeled oligonucleotides containing AP-1 sites, a much more discrete band was formed (lanes 6 and 7 ) that migrated slightly faster. This DNA-protein complex comigrated with the ${ }^{32} \mathrm{P}$-labeled AP-1 band generated by gel-shift assay using Fos-Jun complexes (lane 8). Although these data indicate that the AP-1 site had an effect on formation of the Fos-Jun protein complex, no increase in the rate or extent of complex formation in the presence of oligonucleotides containing AP-1 sites was detected by co-immunoprecipitation assays (data not shown). It is possible that the AP-1 oligonucleotides simply encouraged a tighter or more uniform packing of the complex.

\section{Fos increases the stability of the AP-1 complex}

The data shown in Figures 5-7 suggest that the affinity of the Fos-Jun complex for the AP-1 site is higher than that of Jun alone. Affinity is a function of both the rate of association and the rate of dissociation. Attempts to measure the on rate of Jun and Fos-Jun complexes to the AP-1 site revealed that it was extremely rapid and little or no difference could be detected (data not shown). Therefore, to address the possible cause of the increased affinity of the Fos-Jun complex for DNA, we decided to measure the half-lives of the respective DNA-protein complexes. For this purpose it was important to form the DNA-protein complexes at saturating levels of oligonucleotide. The complexes were formed by incubation of Fos-Jun complexes with the AP-1 for 15 min, then a 30-fold excess of unlabeled oligonucleotide was added. After a further 1-15 min of incubation, samples were chilled and immediately analyzed by electrophoresis on low-ionic-strength gels (Fig. 9). Because the unlabeled oligonucleotide was in excess, it replaced the majority of the ${ }^{32}$ P-labeled AP-1 oligonucleotides that dissociated during the incubation period. Thus, the decrease in amount of the gel-shift band that occurred with time gave a measure of the stability of the protein-DNA complex.

The Jun-DNA complex dissociated very rapidly such that it was reduced to a basal level even after $1 \mathrm{~min}$ of incubation with excess competitor. In fact, the Jun gelshift activity disappeared after as little as $30 \mathrm{sec}$ (data not shown). Thus, the half-life of the Jun-AP-1 site complex must be on the order of seconds. In contrast, the DNA-binding activity of the Fos-Jun complex decreased gradually over a 15-min period (Fig. 9). Using this data the half-life of the Fos-Jun-AP-1 site complex was calculated to be $3.5 \mathrm{~min}$. Thus, Fos stabilizes the association of Jun with the AP-1 site.

\section{Discussion}

We have examined the ability of Fos and Jun to form a protein complex in vitro that binds to the AP-1 recognition sequence. The major new finding of this study is that Fos and Jun interact cooperatively with DNA. Fos increases the affinity of Jun for the AP-1 site by stabilizing the protein-DNA association. Our findings are consistent with recent reports of a synergism between 


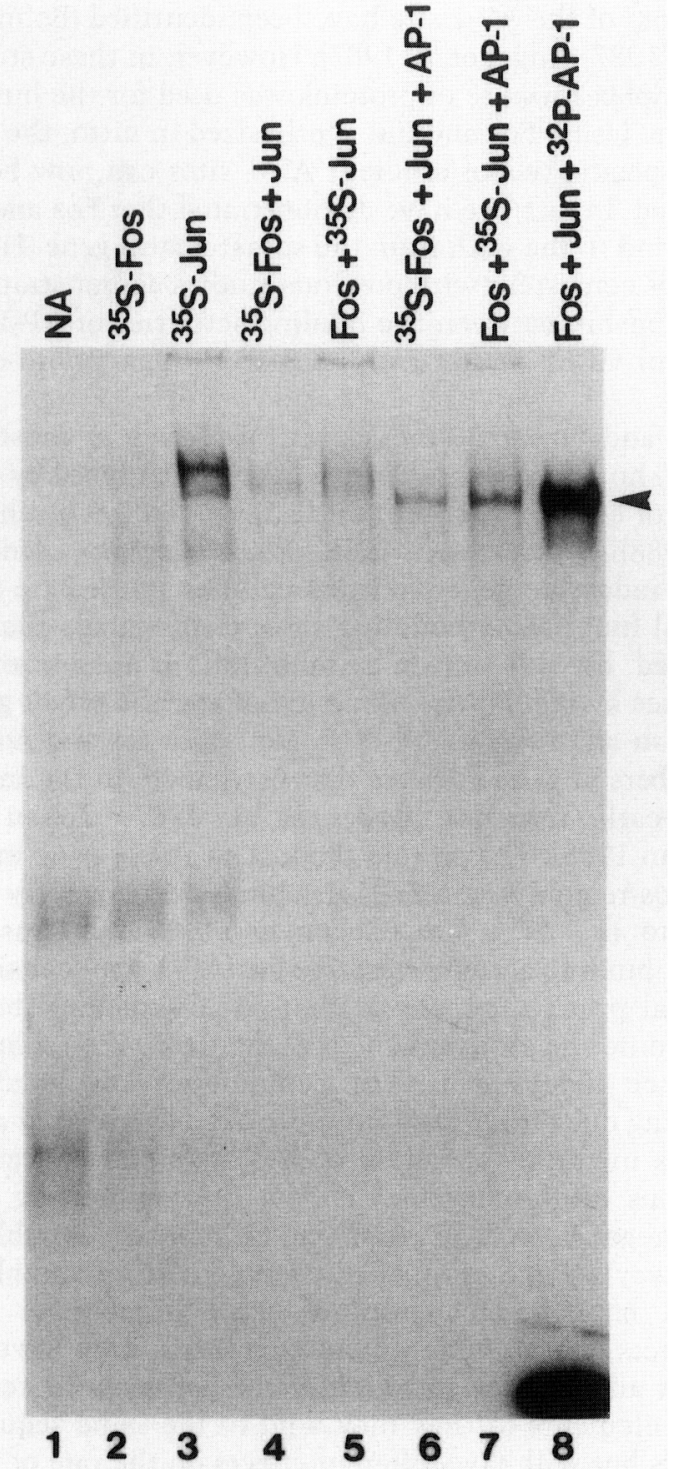

Figure 8. Co-migration of $\left.{ }^{35} \mathrm{~S}\right]$ methionine-labeled Fos and Jun with a [ $\left.{ }^{32} \mathrm{P}\right] \mathrm{AP}-1$ oligonucleotide in gel retardation assays. The migration of $\left[{ }^{35} \mathrm{~S}\right]$ methionine-labeled Fos and Jun in low-ionicstrength gels was determined by performing gel retardation reactions exactly as described for Fig. 5 [including poly(dI-dC)] but without the AP-1 oligonucleotide (lanes 1-5). Reactions contained the following: (lane 1) reticulocyte lysate with $\left[{ }^{35} \mathrm{~S}\right] \mathrm{me}-$ thionine but no RNA; (lane 2) $\left.{ }^{35} S\right]$ methionine-labeled Fos; (lane 3) [ ${ }^{35}$ S]methionine-labeled Jun; (lane 4) [ ${ }^{35}$ S]methionine-labeled Fos preincubated $\left(37^{\circ} \mathrm{C}, 30 \mathrm{~min}\right)$ with unlabeled Jun protein; (lane 5) [ ${ }^{35} \mathrm{~S}$ )methionine-labeled Jun preincubated with unlabeled Fos protein. Lanes 6 and 7 are identical to lanes 4 and 5, respectively, except that unlabeled AP-1 site oligonucleotide was added (0.6 $\mu \mathrm{M}$ final concentration) to the gel retardation reactions and incubated for $15 \mathrm{~min}$. (Lane 8 ) Gel retardation reaction performed with an aliquot of unlabeled Fos-Jun complex and ${ }^{32}$ P-labeled AP-1 oligonucleotide. The arrow indicates the major band of retarded ${ }^{32} \mathrm{P}$-labeled oligonucleotide which comigrated with the ${ }^{35} S \mid$ methionine-labeled proteins shown in lanes 4 and 5 .

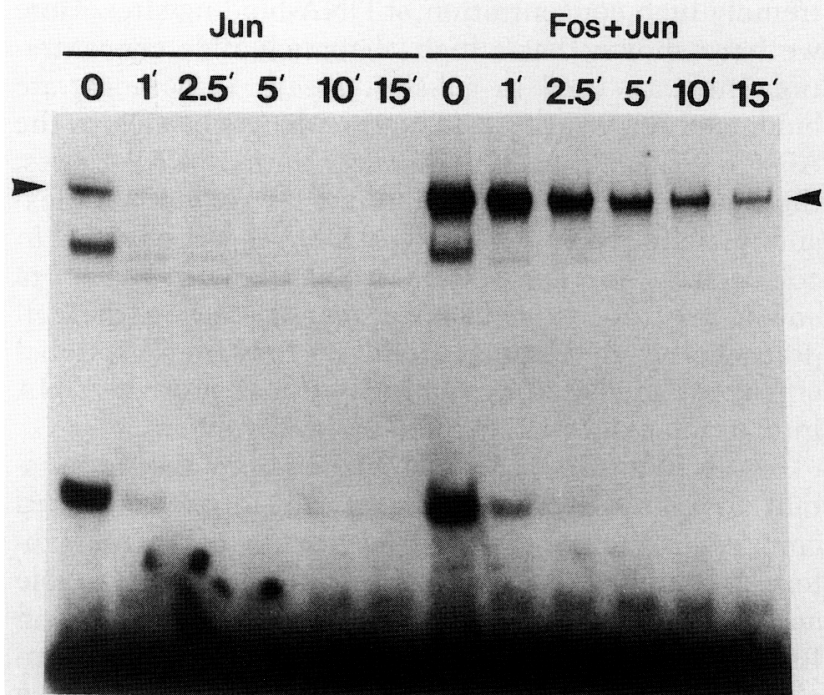

Figure 9. The Fos-Jun-DNA complex is more stable than the Jun-DNA complex. In vitro-synthesized Jun or Fos-Jun complexes were used in gel binding reactions with a saturating concentration $(0.26 \mu \mathrm{M})$ of [ $\left.{ }^{32} \mathrm{P}\right] \mathrm{AP}-1$ oligonucleotide. After $15 \mathrm{~min}$ incubation with [ $\left.{ }^{32} \mathrm{P}\right] \mathrm{AP}-1$ DNA, a 30 -fold excess of unlabeled AP-1 DNA was added. At the indicated times (minutes after addition of unlabeled DNA, reactions were placed on ice and loaded quickly onto a low-ionic-strength gel. The arrowheads indicate the Jun-DNA and the Fos-Jun-DNA complexes.

Fos and Jun in trans-activation assays (Chui et al. 1988; Lamph et al. 1988). Several other transcription factors have been shown to consist of protein complexes. The interaction of the ovalbumin gene-specific transcription factor (COUP) with DNA is stabilized by a non-DNAbinding factor (Tsai et al. 1987). The yeast transcriptional activators HAP2 and HAP3 form a multimeric complex in the absence of DNA that recognizes the CCAAT box (Hahn and Guarente 1988). Similar CCAAT box-binding complexes have been identified in mammalian cells (Chodosh et al. 1988a; Hatamochi et al. 1988; van Wijnen et al. 1988). Remarkably, some of the yeast and human subunits are functionally interchangeable (Chodosh et al. 1988b). In these cases cooperativity is mediated by protein-protein interaction. However, cooperativity has also been observed between two different DNA-binding sites and a single protein (Davidson et al. 1988; Landschulz et al. 1988a).

Previously, purified recombinant Jun proteins were shown to possess AP-1 DNA binding activity according to footprinting and affinity chromatography assays (Bohmann et al. 1987; Bos et al. 1988). However, the data presented here demonstrate that the Fos-Jun complex has a much higher apparent affinity for the same AP-1 site (Fig. 7). One major difference between these studies is that a much higher concentration of recombinant Jun protein was used for footprinting analysis. This would not allow the discrimination of low-affinity and highfinity DNA-binding activities. Similarly, oligonucleotide concentration may affect the ability of certain assays to discriminate between high- and low-affinity interactions. For example, affinity columns have an ex- 
tremely high concentration of DNA-binding sites. Here we have shown that a high oligonucleotide concentration must be used in gel-shift assays to demonstrate binding of Jun, synthesized in reticulocyte lysates, to the AP-1 site (Fig. 7). At a high concentration of AP-1 sites, the difference between high-affinity (Fos-Jun complex) and low-affinity (Jun) binding to DNA is not obvious. In cell extracts, Jun is found in association with Fos or Fra and it may not exist in an unbound state in the cell (Rauscher et al. 1988b). It is likely that transcriptional effects are mediated by the high-affinity protein-DNA interaction exhibited by the Fos-Jun complex.

Fos and Jun form a very stable complex that is resistant to high salt and detergent. The in vitro-formed complex is similar, but not identical, to the in vivoformed complex (Fig. 4). However, it is also very stable and no dissociation was detected after incubation in RIPA buffer for up to $18 \mathrm{hr}$ (data not shown). This implies an unusual and intimate association of the two proteins. Landschulz et al. (1988a) recently presented a model to explain the dimerization and DNA-binding properties of an enhancer and CCAAT-box binding protein (C/EBP) (Landschulz et al. 1988) that may apply to the Fos-Jun complex. They identified a structural motif, termed the 'leucine zipper,' that consists of a periodic repetition of leucine residues every seven amino acids. When arranged on an idealized $\alpha$-helix the leucines appear on one face of the helix, at every second turn, over a distance of eight turns. They propose that the leucine side-chains from one $\alpha$-helix interdigitate with those from a second forming a strong hydrophobic interaction that mediates dimerization. Such an association could give rise to Jun-Jun homodimeric and FosJun heterodimeric complexes. Indeed, recent mutagenesis studies suggest that the leucine-containing region is required for Fos-Jun association (R.L. Gentz, F.J. Rauscher III, and T. Curran, in prep.). In the C/EBP protein the leucine zipper domain is not thought to contact DNA directly; instead, it may juxtapose two other regions that provide this function.

In the case of the Fos-Jun complex two models can be proposed that explain the contribution of Fos to the DNA-binding properties of the Fos-Jun complex. (1) The low affinity of Jun for the AP-1 site may be converted to a high-affinity interaction by an allosteric effect of Fos. In this model Fos would not contact DNA directly. (2) Formation of the Fos-Jun complex may create a DNA-binding domain that is contributed to by both Fos and Jun. It is interesting to note that Fos and Jun show sequence similarity in the zipper region and in an adjacent highly charged domain (Vogt et al. 1987; Cohen and Curran 1988). The highly charged region contains clusters of basic amino acids and is a potential DNA-binding domain. An attractive possibility is that in the heteromeric Fos-Jun complex a DNA binding domain of Fos replaces a Jun DNA-binding domain that is present in a homomeric Jun complex. Mutagenesis studies support the idea that Fos has a DNA-binding domain \{R.L. Gentz, F.J. Rauscher III, and T. Curran, in prep.).
The AP-1 site is found in many different regulatory elements (Angel et al. 1987; Lee et al. 1987b; Franza et al. 1988; Rauscher et al. 1988a) and many different variants of the AP-1 site have been identified (Bohmann et al. 1987; Angel et al. 1987). However, in these studies a complex mixture of proteins was used for the binding assays. Using Fos and Jun synthesized in vitro, the relative specificities of different AP-1 sites can now be examined. In fact, we have demonstrated that Fos and Jun can bind to the CRE from the somatostatin gene (Fig. 6). This is consistent with previous studies demonstrating a relationship between the binding activities of AP-1 and ATF or CREB (Hurst and Jones 1987; Yamamoto et al. 1988).

fos and jun are expressed at low levels in most cell types; however, their expression can be induced by a variety of extracellular stimuli (Curran 1988; Rauscher et al. 1988b; Ryseck et al. 1988). It has been proposed that such inducible genes (termed cellular immediate-early genes) function in coupling short-term signals that are elicited by cell-surface stimulation to long-term responses by regulating expression of specific target genes (Curran and Morgan 1987). In fact, both fos and jun are members of gene families that participate in the immediate-early response (Ryder et al. 1987; Cohen and Curran 1988). The protein product of at least one inducible fos-related gene (Fra-1) also binds cooperatively with Jun to the AP-1 site (Cohen et al. 1989). Thus, the DNA-binding activity described as AP-1 may consist of several protein complexes that have variable subunits with differing affinities and specificities. These subunits may be independently or coordinately regulated depending on cell type or stimulus. In fact, temporal alterations in the composition of AP-1 complexes occur in neurons after induction of Fos (J.L. Sonnenberg, P.F. Macgregor-Leon, T. Curran, and J.I. Morgan, unpubl.). In this way a large number of gene regulatory complexes could be generated from a small number of gene products. These heteromeric complexes may have different affinities or specificities for half-sites in certain AP-1 elements or they may bind to the same sequence motifs but will have different effects on the rate of transcription. The collection of proteins that comprise AP-1 activity may fulfill a signal transduction function, adapted for use by several second-messenger systems and different subsets of target genes, that provides a flexible cellular response to a changing extracellular environment.

\section{Materials and methods}

\section{$c$-fos(rat) and c-jun(rat) cDNA clones}

The isolation and characterization of a full-length clone of c-fos(rat) has been described previously (Curran et al. 1987). The 2.1-kbp insert subcloned into the EcoRI site of pSP65 was used to generate positive-sense RNA as described (Curran et al. 1987). To isolate a c-jun(rat) cDNA clone, a cDNA library, constructed using RNA from serum-stimulated rat fibroblasts (Cohen and Curran 1988), was screened with a c-jun(human) probe (Bohmann et al. 1987). Approximately $5 \times 10^{5}$ plaques were screened and 12 positives were obtained. The largest 
EcoRI insert $(1.8 \mathrm{kbp})$ was isolated and subcloned into the EcoRI site of pGEM-4 vector (Promega Biotech). Nucleotide sequence analysis (to be presented in detail elsewhere) confirmed the presence of the complete c-jun open reading frame in this cDNA. Plasmid DNA was linearized by digestion with BamHI and positive-sense RNA was transcribed in vitro using SP6 polymerase under the conditions specified by the supplier.

\section{In vitro translation}

Nuclease-treated messenger-dependent rabbit reticulocyte lysates were obtained from Promega Biotech. Standard reactions contained $40 \mu$ l of lysate, $1 \mathrm{~mm}$ amino acids minus methionine, $0.5 \mu \mathrm{g}$ of RNA, and $20 \mu \mathrm{Ci}$ of ${ }^{35}$ S]methionine (sp. act. $\sim 300$ $\mu \mathrm{Ci} / \mathrm{mmole}$, Amersham) in a total volume of $50 \mu \mathrm{l}$. Unlabeled proteins were synthesized in the absence of $\left[{ }^{35} \mathrm{~S}\right] \mathrm{methionine}$ in lysates supplemented with $1 \mathrm{mM}$ methionine (Sigma Chemical Co.). Translations were carried out for up to $60 \mathrm{~min}$ at $30^{\circ} \mathrm{C}$. Protein products were either analyzed directly by electrophoresis on SDS polyacrylamide gels or after immunoprecipitation. Immunoprecipitation was carried out using anti-Fos antibodies generated and affinity-purified against a synthetic peptide corresponding to Fos amino acids 127-152 (Curran et al. 1985); anti-Jun antibodies raised against synthetic peptides corresponding to amino acids 73-87 and 209-225 (Bos et al. 1988); or anti-Jun antibodies raised against a $19-\mathrm{kD}$ carboxy-terminal Jun polypeptide expressed in E. coli (Bohmann et al. 1987). The anti-Jun antibodies were kind gifts of D. Bohmann and R. Tjian (University of California, Berkeley) and T.J. Bos and P.K. Vogt (University of Southern California Medical School). The immunoprecipitation procedure was essentially as described (Curran et al. 1987).

\section{In vitro association of Fos and Jun}

For in vitro association, equal volumes of reticulocyte lysate containing Fos or Jun proteins were combined and incubated at $37^{\circ} \mathrm{C}$. At various times aliquots (usually $6 \mu$ l) were removed and diluted to $0.3 \mathrm{ml}$ with ice-cold RIPA buffer and proteins were immunoprecipitated. In some instances, lysates were treated with DNase-free RNase A at a concentration of $0.5 \mu \mathrm{g} / \mu \mathrm{l}$ for 30 min at $37^{\circ} \mathrm{C}$ or with alkaline phosphatase (Boehringer Mannheim) $1.5 \mathrm{U} / \mu \mathrm{l}$ for $30 \mathrm{~min}$ at $37^{\circ} \mathrm{C}$, prior to analysis on gels or use in association assays.

\section{Sucrose gradients and gel filtration analyses}

Linear $5-20 \%$ sucrose gradients were prepared by layering 1.1 $\mathrm{ml}$ volumes of $5 \%, 10 \%, 15 \%$, or $20 \%$ sucrose solutions prepared in Buffer B [10 mM sodium phosphate $(\mathrm{pH} 7.0), 140 \mathrm{~mm}$ $\mathrm{NaCl}, 0.5 \% \mathrm{NP}-40,1 \mathrm{~mm}$ phenylmethylsulfonyl fluoride (PMSF), $2 \mu \mathrm{g} / \mathrm{ml}$ aprotinin, $3 \mu \mathrm{g} / \mathrm{ml}$ leupeptin] onto a $0.4-\mathrm{ml}$ cushion of $60 \%$ sucrose in prepared Buffer B. After incubation for $1 \mathrm{hr}$ at $20^{\circ} \mathrm{C}$ and $1 \mathrm{hr}$ at $4^{\circ} \mathrm{C}$ a $200-\mu \mathrm{l}$ sample containing molecular weight markers and the Fos-Jun complex to be tested was layered onto the gradient. The sample of in vitrosynthesized Fos-Jun complex was prepared by co-translating Fos and Jun RNAs in a final reticulocyte lysate volume of $60 \mu \mathrm{l}$. To determine the efficiency of recovery from the gradient, $10 \mu \mathrm{l}$ was removed, diluted to $500 \mu 1$ with RIPA buffer, and immunoprecipitated alongside the rest of the fractions. The remaining $50 \mu \mathrm{l}$ was diluted to $200 \mu \mathrm{l}$ with Buffer B containing $10 \mu \mathrm{g}$ of each marker protein. The marker proteins used for sucrose gradients and gel filtration were: Ferritin, $440 \mathrm{kD}$; Catalase, 230 $\mathrm{kD}$; Aldolase, $160 \mathrm{kD}$; bovine serum albumin, $67 \mathrm{kD}$; ovalbumin, $43 \mathrm{kD}$; and chymotrypsinogen, $25 \mathrm{kD}$ (Pharmacia Inc.). The in vivo Fos-Jun complex was prepared from $208 \mathrm{~F}$ rat fibroblasts that were serum-stimulated and labeled with $\left[{ }^{35} \mathrm{~S}\right] \mathrm{methi}-$ onine as described previously (Rauscher et al. 1988b). Nuclei prepared from stimulated cells were extracted with Buffer B containing $0.42 \mathrm{M} \mathrm{NaCl}$. After removal of a sample for recovery, the extract was combined with marker proteins in Buffer $B$ and layered onto gradients. Gradients were centrifuged in a SW50.1 rotor at $45,000 \mathrm{rpm}$ for $18 \mathrm{hr}$. Approximately 20 fractions each containing $250 \mu \mathrm{l}$ were collected from the bottom of the tube. Aliquots $(25 \mu 1)$ of each fraction were analyzed by gel electrophoresis, followed by staining with Coomassie Brilliant Blue, to determine the migration of marker proteins. The remainder of each fraction was diluted to $0.8 \mathrm{ml}$ with RIPA buffer and immunoprecipitated with anti-Fos antibodies (in vitro-formed complexes). The Fos-Jun complex from $208 \mathrm{~F}$ cells was detected using Fos- 1 antisera [raised against a Fos- $\beta$-Gal fusion protein and kindly provided by D. Slamon (UCLA Medical Schooll].

Analysis of the Fos-Jun complex by gel filtration was performed on a Waters FPLC using a 300 SW Protein-PAK column. The column was equilibrated with Buffer $B$ at a flow rate of 0.2 $\mathrm{ml} / \mathrm{min}$ and migration of the marker proteins finjected in volume of $50 \mu$ l) was determined by absorbance at $280 \mathrm{~nm}$. The in vitro- or in vivo-formed Fos-Jun complexes prepared exactly as described for sucrose gradients were applied to the column in a $50-\mu l$ volume. Twenty-four fractions containing $0.8 \mathrm{ml}$ were collected and processed by immunoprecipitation and gel electrophoresis, as described above.

\section{Gel retardation assays}

Equal volumes of in vitro-synthesized Fos and Jun were associated by incubation at $37^{\circ} \mathrm{C}$ for $30 \mathrm{~min}$. Reactions containing Fos or Jun alone were incubated with an equal volume of reticulocyte lysate minus RNA. Three microliters of the in vitro association reaction was combined with $5 \mu \mathrm{l}$ of binding buffer [10 mM Tris- $\mathrm{HCl}$ (pH 7.9), $50 \mathrm{~mm} \mathrm{MgCl}, 1 \mathrm{~mm} \mathrm{DTT,} 1$ mM EDTA, $5 \%$ glycerol, $5 \%$ sucrose, $1 \mathrm{mM}$ PMSF, $2 \mu \mathrm{g} / \mathrm{ml}$ aprotinin, 3 $\mu \mathrm{g} / \mathrm{ml}$ leupeptin)], and $1 \mu \mathrm{g}$ poly(dI-dC) nonspecific competitor DNA (Pharmacia Inc.). After $15 \mathrm{~min}$ at room temperature, $1 \mu \mathrm{l}$ of ${ }^{32} \mathrm{P}$-labeled oligonucleotide probe was added and incubation was continued for $15 \mathrm{~min}$. After placing on ice and addition of 1 $\mu l$ of loading buffer, DNA-protein complexes were separated from unbound DNA in nondenaturing $5 \%$ acrylamide gels by electrophoresis at 200 volts for $1.5-2 \mathrm{hr}$. The running buffer consisted of $45 \mathrm{mM}$ Tris-borate (pH 8.3), $45 \mathrm{~mm}$ boric acid, and $1 \mathrm{~mm}$ EDTA. Gels were fixed in $10 \%$ acetic acid for $15 \mathrm{~min}$ prior to drying and autoradiography. Gel retardation assays using $\left.{ }^{35} S\right]$ methionine-labeled proteins were performed exactly as described above except that unlabeled oligonucleotide was used (where noted) and gels were enhanced with PPO-POPOP prior to drying. The AP-1 and GPD oligonucleotides used are described in Rauscher et al. (1988a). Oligonucleotides were labeled by filling in recessed 3 ' ends with the large fragment of $E$. coli DNA polymerase or reverse transcriptase and three or four $\left[\alpha^{-32}\right.$ P]-labeled dNTPs (Maniatis et al. 1982). Specific activities ranged from 0.2 to $1.0 \times 10^{6} \mathrm{cpm} / \mathrm{pmole}$. Unlabeled competitor DNAs, when used, were added at the same time as the labeled oligonucleotide. Antibodies were added at the same time as nonspecific poly (dI-dC) competitor DNA. To determine the rate of dissociation, binding reactions were first performed as described above; then, after the 15 -min incubation with labeled oligonucleotide, a 30-fold molar excess of unlabeled homologous AP-1 oligonucleotide was added. The reactions were stag. gered such that all reactions were stopped at the same time (by quickly chilling tubes at $0^{\circ} \mathrm{C}$ ) and were immediately loaded onto native gels. Following autoradiography, bands containing radioactive oligonucleotide in the dried gel were removed and Cerenkov counts were determined. 


\section{DNA affinity precipitation assays}

DNAP assays using biotinylated oligonucleotides were performed essentially as described in Franza et al. (1987a). Briefly, binding reactions were assembled using $\left[{ }^{35} S \mid\right.$ methionine-labeled Fos and Jun synthesized in vitro (total volume of lysate 10-12 $\mu \mathrm{l})$, poly(dI-dC) competitor DNA at 40 - or 100 -fold excess (by weight) over the specific oligonucleotide, and a sufficient amount of Buffer B [50 mM Tris- $\mathrm{HCl}(\mathrm{pH} 8.0), 0.01 \%$, NP-40, 20\% glycerol, $1.5 \mathrm{~mm} \mathrm{MgCl} 2,1 \mathrm{~mm}$ dithiothreitol, and 1 $\mathrm{mM}$ PMSF] to form a $60-\mu \mathrm{l}$ volume. After $15 \mathrm{~min}$ at $37^{\circ} \mathrm{C}, 20$ pmoles of biotinylated oligonucleotide was added and incubation was continued for $20 \mathrm{~min}$. Then, streptavidin-agarose beads (Bethesda Research Laboratories) were added and the mixture was incubated for a further $20 \mathrm{~min}$ at room temperature. Reaction mixes were clarified by centrifugation for $5 \mathrm{sec}$ in a microfuge, and the pellets were washed four times in Buffer B containing $50 \mathrm{~mm} \mathrm{KCl}$ and $5 \mathrm{~mm} \mathrm{NaF}$. Proteins were eluted from the beads by boiling for $3 \mathrm{~min}$ in $2 \times$ Laemmli sample buffer and analyzed by SDS-PAGE and autoradiography. The oligonucleotides used in this study are listed below.

DGALV

5'-TCGAACAGAAATAGATGAGTCAACAGCAGATACAGAAATAGATGAGTCAACAGCAG-3

3'-TGTCTTTATCTACTCAGTTGTCGTCTATGTCTTTATCTACTCAGTTGTCGTCAGCT-5'

DAP.1

5'-TCGACGTGACTCAGCGCGCATCGTGACTCAGCGCGC-3'

3'-GCACTGAGTCGCGCGTAGCACTGAGTCGCGCGAGCT-5

STAT

5'-GCGCTCCTTGGCTGACG TCAGAGAGAGAG-3'

3'.CGCGAGGAACCGACTGCAGTCTCTCTCTC-5

Kappa B

5'-CAGAGGGGACTTTCCGAGAGGCAGAGGGGACTTTCCGAGAGG-3'

3'.GTCTCCCCTGAAAGGCTCTCCGTCTCCCCTGAAAGGCTCYCC.5'

The DGALV sequence is a two-time iterated sequence from the Gibbon-ape leukemia virus long terminal repeat (LTR) identified as sufficient for enhancer activity (Quinn et al. 1987). The DAP- 1 is a two-time iterated sequence of the AP- 1 binding site contained in the human metallothionein $\mathrm{II}_{\mathrm{A}}$ gene (Lee et al. $1987 \mathrm{a})$. The STAT oligonucleotide is from a region of the human somatostatin gene enhancer identified as cAMP-responsive element (Montminy et al. 1986). The Kappa B sequence is a two-time iterated sequence identified by Sen and Baltimore (1986) in the human immunoglobulin enhancer which contains an NFKB binding site.

\section{Acknowledgments}

We wish to thank J.D. Watson for his continuous support; Mr. Philip Renna for his photographic assistance; T. Bos and P. Vogt, USC Medical School, for anti-Jun antibodies; and D. Bohmann and R. Tjian, UC Berkeley, for anti-Jun antibodies and the c-jun(human) cDNA clone. This work was supported in part by grants from the National Cancer Institute (CA-40512, B.R.F.), the Cancer Research Institute of New York (B.R.F.|, and the American Foundation for AIDS Research (B.R.F.).

\section{References}

Angel, P., M. Imagawa, R., Chiu, B. Stein, R.J. Imbra, H.J. Rahmsorf, C. Jonat, P. Herrlich, and M. Karin. 1987. Phor- bolester-inducible genes contain a common cis-element recognized by a TPA-modulated trans-acting factor. Cell 49: 729-739.

Bohmann, D., T.J. Bos, A. Admon, T. Nishimura, P.K. Vogt, and R. Tjian. 1987. Human proto-oncogene c-jun encodes a DNA-binding protein with structural and functional properties of transcription factor AP-1. Science 238: 1386-1392.

Bos, T.J., D. Bohmann, H. Tsuchie, R. Tjian, and P.K. Vogt. 1988. v-jun encodes a nuclear protein with enhancer binding properties of AP-1. Cell 52: 705-712.

Breathnach, R. and P. Chambon. 1981. Organization and expression of eukaryotic split genes coding for proteins. Annu. Rev. Biochem. 50: 349-383.

Carroll, R.B., A. Samad, A. Mann, J. Harper, and C.W. Anderson. 1988. RNA is covalently linked to SV40 large T antigen. Oncogene 2: 438-444.

Chiu, E., W.J. Boyle, J. Meek, T. Smeal, T. Hunter, and M. Karin. 1988. The c-fos protein interacts with a c-jun//AP-l to stimulate transcription of AP-1 responsive genes. Cell 54: $541-552$.

Chodosh, L.A., A.S. Baldwin, R.W. Carthew, and P.A. Sharp. 1988a. Human CCAAT-binding proteins have heterologous subunits. Cell 53: 11-24.

Chodosh, L.A., J.A. Olesen, S. Hahn, A.S. Baldwin, L. Guarente, and P.A. Sharp. 1988b. A yeast and a human CCAATbinding protein have heterologous subunits that are functionally interchangeable. Cell 53: 25-35.

Cohen, D.R. and T. Curran. 1988. Fra-1: A serum inducible cellular immediate-early gene that encodes a Fos-related antigen. Mol. Cell. Biol. 8: 2063-2069.

Curran, T. 1988. The fos oncogene. In The oncogene handbook (ed. E.P. Reddy, A.M. Skalka, and T. Curran), pp. 307-325. Elsevier Science Publishers, Amsterdam.

Curran, T. and J.I. Morgan. 1987. Memories of fos. BioEssays 7: $255-258$

Curran, T. and N.M. Teich. 1982a. Candidate product of the FBJ murine osteosarcoma virus oncogene: Characterization of a 55,000 dalton phosphoprotein. J. Virol. 42: 114-122.

- 1982b. Identification of a 39,000 dalton protein in cells transformed by FBJ murine osteosarcoma virus. Virology 116: $221-235$.

Curran, T. and I.M. Verma. 1984. The FBR murine osteosarcoma virus. I. Molecular analysis and characterization of a 75,000 gag-fos fusion product. Virology 135: 218-228.

Curran, T., A.D. Miller, L. Zokas, and I.M. Verma. 1984. Viral and cellular fos proteins: A comparative analysis. Cell 36: $259-268$.

Curran, T., C. Van Beveren, N. Ling, and I.M. Verma. 1985. Viral and cellular Fos proteins are complexed with a 39,000 cellular protein. Mol. Cell. Biol. 5: 167-172.

Curran, T., M.B. Gordon, K.L. Rubino, and L.C. Sambucetti. 1987. Isolation and characterization of the c-fos (rat) cDNA and analysis of post-translational modification in vitro. Oncogene 2: 79-84.

Davidson, I., J.H. Xiao, R. Rosales, A. Staub, and P. Chambon. 1988. The HeLa cell protein TEF-1 bind specifically and cooperatively to two SV-40 enhancer motifs of unrelated sequence. Cell 54: 931-942.

Distel, R.J., H.-S. Ro, B.S. Rosen, D.L. Groves, and B.M. Spiegelman. 1987. Nucleoprotein complexes that regulate gene expression in adipocyte differentiation: Direct participation of c-fos. Cell 49: 835-844.

Franza, B.R., Jr., S.F. Josephs, M.Z. Gilman, W. Ryan, and B. Clarkson. 1987a. Characterization of cellular proteins recog. nizing the HIV enhancer using a microscale DNA-affinity precipitation assay. Nature 330: 391-395. 
Franza, B.R., Jr., L.C. Sambucetti, D.R. Cohen, and T. Curran. 1987b. Analysis of Fos protein complexes and Fos-related antigens by high-resolution of two-dimensional gel electrophoresis. Oncogene 1: 213-221.

Franza, B.R., Jr., F.J. Rauscher III, S.F. Josephs, and T. Curran. 1988. The Fos complex and Fos-related antigens recognize sequence elements that contain AP-1 binding sites. Science 239: $1150-1153$.

Graves, B.J., P.F. Johnson, and S.L. McKnight. 1986. Homologous recognition of a promoter domain common to the MSV LTR and the HSV tk gene. Cell 44: 565-576.

Hahn, S. and L. Guarente. 1988. Yeast HAP2 and HAP3: Transcriptional activators in a heteromeric complex. Science 240: $318-321$.

Hatamochi, A., P.T. Golumbek, E. van Schaftingin, and B. de Crombrugghe. 1988. A CCAAT DNA binding factor consisting of two different components that are both required for DNA binding. J. Biol. Chem. 263: 5940-5947.

Hill, D.E., I.A. Hope, J.P. Macke, and K. Struhl. 1986. Saturation mutagenesis of the yeast his3 regulatory site: Requirements for transcriptional induction and for binding of GCN4 activator protein. Science 234: 451-457.

Hope, I.A. and K. Struhl. 1986. Functional dissection of a eukaryotic transcriptional activator protein, GCN4 of yeast. Cell 46: 885-894.

- 1987. GCN4, a eukaryotic transcriptional activator protein binds as a dimer to target DNA. EMBO J. 6: 2781-2784.

Hurst, H.C. and N. Jones. 1987. Identification of factors that interact with the EIA-inducible adenovirus E3 promoter. Genes Dev. 1: 1132-1146.

Klekamp, M.S. and P.A. Weil. 1987. Properties of yeast class III transcriptional factor TFIIB: Implications regarding mechanism of action. J. Biol. Chem. 262: 7878-7883.

Lamph, W.W., P. Wamsley, P. Sassone-Corsi, and I.M. Verma. 1988. Induction of proto-oncogene Jun/AP-1 by serum and TPA. Nature 334: 629-631.

Landschulz, W.M., P.F. Johnson, and S.L. McKnight. 1988a. The leucine zipper: A hypothetical structure common to a new class of DNA binding proteins. Science 240: 1759-1764.

Landschulz, W.M., P.F. Johnson, E.Y. Adashi, B.J. Graves, and S.L. McKnight. 1988b. Isolation of a recombinant copy of the gene encoding C/EBP. Genes Dev. 2: 786-800.

Lee, W., A. Haslinger, M. Karin, and R. Tjian. 1987a. Two factors that bind and activate the human metallothionein IIA gene in vitro also interact with the SV40 promoter and enhancer regions. Nature 325: 368-372.

Lee, W., P. Mitchell, and R. Tjian. 1987b. Purified transcription factor AP-1 interacts with TPA-inducible enhancer elements. Cell 49: 741-752.

Maki, Y., T.J. Bos, C. Davis, M. Starbuck, and P.K. Vogt. 1987. Avian sarcoma virus 17 carries a new oncogene, jun. Proc. Natl. Acad. Sci. 84: 2848-2852.

Maniatis, T., E.F. Fritsch, and J. Sambrook. 1982. Molecular cloning: A laboratory manual. Cold Spring Harbor Laboratory, Cold Spring Harbor, New York.

Maniatis, T., S. Goodbourn, and J.A. Fisher. 1987. Regulation of inducible and tissue-specific gene expression. Science 236: 1237-1245.

McKnight, S.L. and R. Tjian. 1986. Transcriptional selectivity of viral genes in mammalian cells. Cell 46: 795-805.

Montminy, M.R., K.A. Sevarino, J.A. Wagner, G. Mandell, and L.H. Goodman. 1986. Identification of cyclic-AMP-responsive element within the rat somatostatin gene. Proc. Natl. Acad. Sci. 83: 6682-6686.

Myers, R.M., K. Tilly, and T. Maniatis. 1986. Fine structure genetic analysis of a $\beta$-globin promoter. Science 232: 613-618.
Piette, J. and M. Yaniv. 1987. Two different factors bind to the a-domain of the polyoma virus enhancer, one of which also interacts with the SV-40 and c-fos enhancers. EMBO $J$. 6: $1331-1337$.

Quinn, J.P., N. Holbrook, and D. Levens. 1987. Binding of a cellular protein to the gibbon ape leukemia virus enhancer. Mol. Cell. Biol. 7: 2735-2744.

Rauscher, F.J. III, L.C. Sambucetti, T. Curran, R.J. Distel, and B.M. Spiegelman. 1988a. Common DNA binding site for Fos protein complexes and transcription factor AP-1. Cell 52: 471-480.

Rauscher, F.J. III, D.R. Cohen, T. Curran, T.J. Bos, P.K. Vogt, D. Bohmann, R. Tjian, and B.R. Franza, Jr. 1988b. Fos-associated protein $\mathrm{p} 39$ is the product of the jun proto-oncogene. Science 240: 1010-1016.

Ryder, K., L.F. Lau, and D. Nathans. 1987. A gene activated by growth factors is related to the oncogene v-jun. Proc. Natl. Acad. Sci. 85: 1487-1491.

Ryseck, R.P., S.I. Hirai, M. Yaniv, and R. Bravo. 1988. Transcriptional activation of c-jun during the G0/G1 transition in mouse fibroblasts. Nature 334: 535-537.

Samad, A., C.W. Anderson, and R.B. Carroll. 1986. Mapping of phosphomonoester and apparent phosphodiester bonds of the oncogene product p53 from simian virus 40-transformed 3 T3 cells. Proc. Natl. Acad. Sci. 897-901.

Sambucetti, L.C. and T. Curran. 1986. The Fos protein complex is associated with DNA in isolated nuclei and binds to DNA cellulose. Science 234: 1417-1419.

Sen, R. and D. Baltimore. 1986. Multiple nuclear factors interact with the immunoglobulin enhancer sequences. Cell 46: $705-716$.

Tsai, S.V., I. Sagami, H. Wang, M.J. Tsai, and B.W. O'Malley. 1987. Interactions between a DNA-binding transcription factor (COUP) and a non-DNA binding factor (S300-11). Cell 50: 701-709.

Van Wijnen, A.J., R.F. Massung, J.L. Stein, and G.S. Stein. 1988. Human $\mathrm{Hl}$ histone gene promoter CCAAT-box-binding protein HinF-B is a mosaic factor. Biochemistry 27: 65346541.

Vogt, P.K., T.J. Bos, and R.F. Doolittle. 1987. Homology between the DNA binding domain of the GCN4 regulatory protein of yeast and the carboxyl-terminal region of a protein coded for by the oncogene jun. Proc. Natl. Acad. Sci. 84: 3316-3319.

Yamamoto, K.R. 1985. Steroid receptor regulated transcription of specific genes and gene networks. Annu. Rev. Genet. 19: 209-252.

Yamamoto, K.K., G.A. Gonzalez, W.H. Biggs III, and M.R. Montminy. 1988. Phosphorylation-induced binding and transcriptional efficacy of nuclear factor CREB. Nature 334: 494-498. 


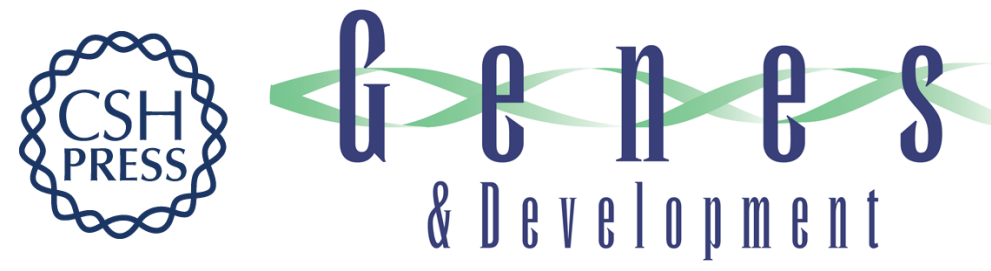

\section{Fos and Jun bind cooperatively to the AP-1 site: reconstitution in vitro.}

F J Rauscher, P J Voulalas, B R Franza, et al.

Genes Dev. 1988, 2:

Access the most recent version at doi:10.1101/gad.2.12b.1687

References This article cites 52 articles, 19 of which can be accessed free at:

http://genesdev.cshlp.org/content/2/12b/1687.full.html\#ref-list-1

License

Email Alerting

Service

Receive free email alerts when new articles cite this article - sign up in the box at the top right corner of the article or click here.

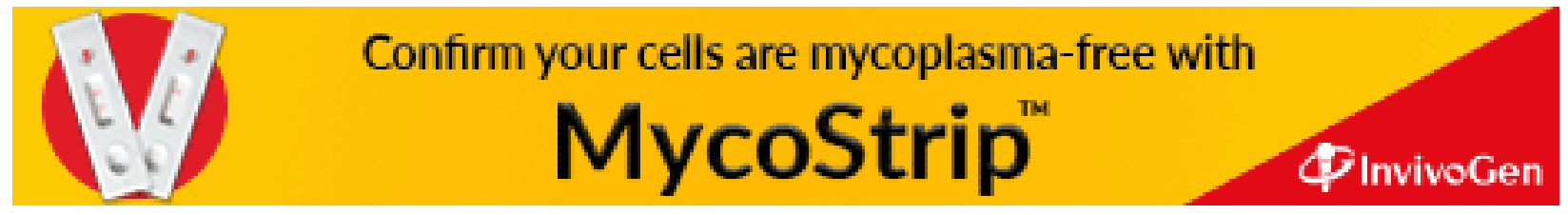

